\title{
Neurotensin Gene Expression and Behavioral Responses Following Administration of Psychostimulants and Antipsychotic Drugs in Dopamine $\mathrm{D}_{3}$ Receptor Deficient Mice
}

Catalina Betancur, M.D., Ph.D., Isabelle Lépée-Lorgeoux, Ph.D., Michèle Cazillis, Ph.D., Domenico Accili, M.D., Sara Fuchs, Ph.D., and William Rostène, Ph.D.

Exposure to psychostimulants and antipsychotics increases neurotensin (NT) gene expression in the striatum and nucleus accumbens. To investigate the contribution of $D_{3}$ receptors to these effects we used mice with targeted disruption of the $D_{3}$ receptor gene. Basal NT mRNA expression was similar in $D_{3}$ receptor mutant mice and wild-type animals. Acute administration of haloperidol increased NT gene expression in the striatum in $D_{3}+/+, D_{3}+/-$ and $D_{3}-/-$ mice. Similarly, acute cocaine and amphetamine induced NT mRNA expression in the nucleus accumbens shell and olfactory tubercle to a comparable extent in $D_{3}$ mutants and wild-type mice. Daily injection of cocaine for seven days increased NT $m R N A$ in a restricted population of neurons in the dorsomedial caudal striatum of $D_{3}+1+$ mice, but not in
$D_{3}-/-$ and $D_{3}+/-$ animals. No differences were observed between $D_{3}$ receptor mutant mice and wild-type littermates in the locomotor activity and stereotyped behaviors induced by repeated cocaine administration. These findings demonstrate that dopamine $D_{3}$ receptors are not necessary for the acute NT $m R N A$ response to drugs of abuse and antipsychotics but appear to play a role in the regulation of NT gene induction in striatal neurons after repeated cocaine. In addition, our results indicate that the acute locomotor response to cocaine and development of psychostimulant-induced behavioral sensitization do not require functional $D_{3}$ receptors. [Neuropsychopharmacology 24:170-182, 2001] (C) 2000 American College of Neuropsychopharmacology. Published by Elsevier Science Inc.
KEY WORDS: Dopamine $D_{3}$ receptor; Neurotensin; Cocaine; Amphetamine; Haloperidol; In situ hybridization;

Behavioral sensitization

The administration of psychostimulants such as cocaine or amphetamine, and antipsychotics-like haloperidol, promotes the expression of the neuropeptide neuro-

From the INSERM U. 339 (CB, ILL, WR) and INSERM U. 142/515 (MC), Hôpital Saint-Antoine, Paris, France; Diabetes Branch, National Institute of Diabetes and Digestive and Kidney Diseases, Bethesda, MD, USA (DA); and Department of Immunology, Weizmann Institute of Science, Rehovot, Israel (SF).

Address correspondence to: Dr. C. Betancur (present address), INSERM U. 513, Faculté de Médecine, 8 rue du Général Sarrail, 94010 Créteil Cedex, France.

Received 28 April 2000; revised 7 July 2000; accepted 19 July 2000. tensin (NT) in the rat striatum and nucleus accumbens (Merchant et al. 1992, 1994a,b; Castel et al. 1994; Betancur et al. 1997). These observations, together with numerous anatomical, behavioral, and neurochemical studies indicating that NT modulates dopamine transmission in the nigrostriatal and mesolimbic pathways (Kasckow and Nemeroff 1991), suggest that alterations in neurotensinergic transmission may be involved in the mechanism of action of neuroleptics and psychostimulant drugs.

Several lines of evidence implicate NT in the etiology of schizophrenia and in the mechanism of action of antipsychotic drugs. NT concentrations in the cerebrospinal fluid are reduced in drug-free schizophrenic patients and increase with clinically effective antipsychotic treatment (Widerlöv et al. 1982; Garver et al. 1991; Sharma et 
al. 1997). The increases in NT mRNA expression and NT content in the nucleus accumbens and striatum after administration of antipsychotic drugs are predictive of clinical efficacy and extrapyramidal side effects, respectively (Merchant and Dorsa 1993; Kinkead et al. 1999).

In rodents, centrally administered NT produces behavioral effects similar to those induced by neuroleptics. Thus, when injected into the nucleus accumbens or the cerebral ventricles, NT blocks psychostimulant-induced locomotor hyperactivity (Ervin et al. 1981; Robledo et al. 1993) and induces a cataleptic response in mice (Snijders et al. 1982). Based on these findings, it has been postulated that NT plays a role as an endogenous neuroleptic (Nemeroff 1980). However, NT has also been implicated in the mechanism of action of psychostimulant drugs, as some of the effects of the neuropeptide resemble those induced by psychostimulants. For instance, injection of NT into the ventral tegmental area increases locomotor activity and dopamine release in the nucleus accumbens (Kalivas et al. 1983; Kalivas and Duffy 1990). Like cocaine, NT possesses rewarding properties: rats self-administer NT into the ventral tegmental area (Glimcher et al. 1987) and injection of NT in the same region induces conditioned place preference (Glimcher et al. 1984). In addition, endogenous NT has been implicated in the locomotor activating properties of cocaine (Betancur et al. 1998) and in the development of psychostimulant-induced behavioral sensitization in rats (Horger et al. 1994).

Previous pharmacological studies have demonstrated that stimulation of $D_{1}$ receptors or blockade of $\mathrm{D}_{2}$ receptors both result in increased expression of NT mRNA in the rat striatum. The effects of cocaine and amphetamine on NT concentration and gene transcription are blocked with selective $\mathrm{D}_{1}$ antagonists (Merchant et al. 1988; Hanson et al. 1989; Castel et al. 1993), whereas the effects of haloperidol appear to involve blockade of $\mathrm{D}_{2}$-like receptors, i.e., $\mathrm{D}_{2}, \mathrm{D}_{3}$, and $\mathrm{D}_{4}$ receptors (Merchant et al. 1989; Augood et al. 1991).

Little is known about the role of dopamine $\mathrm{D}_{3}$ receptors in these effects. $D_{3}$ receptors are primarily expressed in mesolimbic areas associated with cognitive functions and motivated behavior and have been implicated in the antipsychotic effects of neuroleptics as well as in the rewarding effects of drugs of abuse (Sokoloff et al. 1990; Caine and Koob 1993; Pilla et al. 1999; see Shafer and Levant 1998 for a review). Two studies suggest the involvement of $\mathrm{D}_{3}$ receptors in the regulation of NT gene expression. First, administration of $\mathrm{D}_{3}$ receptor antisense oligonucleotides to rats has been reported to reduce NT mRNA expression in the nucleus accumbens shell (Tremblay et al. 1997). Second, blockade of $\mathrm{D}_{2}$-like receptors by haloperidol increases NT mRNA expression in the septal pole of the nucleus accumbens, which contains a high level of $D_{2}$ receptors, but decreases it in the $D_{3}$ receptorrich ventromedial shell, suggesting that $D_{3}$ receptors exert a tonic stimulation of NT expression, as opposed to the inhibitory influence of $\mathrm{D}_{2}$ receptors (Diaz et al. 1994). However, the functional significance of $D_{3}$ receptors in the modulation of NT expression has been difficult to establish due to the lack of selective ligands.

To investigate the selective contribution of $\mathrm{D}_{3}$ receptors to psychostimulant and antipsychotic drug-induced NT mRNA expression we used mice with targeted disruption of the $\mathrm{D}_{3}$ receptor gene (Accili et al. 1996). $\mathrm{D}_{3}$ mutant mice show no overt behavioral abnormalities or major compensatory changes within the dopaminergic system (Accili et al. 1996; Xu et al. 1997). We first studied the acute effects of two indirect dopamine receptor agonists, cocaine and amphetamine, and the $\mathrm{D}_{2}$-like receptor antagonist haloperidol. We also examined the effects of repeated cocaine administration on NT gene expression. Quantitative in situ hybridization histochemistry with $\left[{ }^{35} \mathrm{~S}\right] \mathrm{ATP}-\mathrm{labeled}$ oligonucleotide probes was used to assess NT mRNA expression in the nucleus accumbens and the striatum.

In addition, to further characterize the behavior of $\mathrm{D}_{3}$ mutant mice, we evaluated basal and cocaine-induced locomotor activity, after acute and daily administration of the drug, to examine the role of $\mathrm{D}_{3}$ receptors in the development of behavioral sensitization. The mesolimbic system plays a critical role in the induction and expression of behavioral sensitization to psychostimulants (Pierce and Kalivas 1997). The restricted distribution of the $\mathrm{D}_{3}$ receptor in the projection areas of the mesolimbic system suggests that activation of the $\mathrm{D}_{3}$ receptor may play a role in the locomotor activating properties of psychostimulants. Sensitization requires activation of $D_{1}$-like $\left(D_{1}\right.$ and $D_{5}$ receptors) and $D_{2}$-like dopamine receptors (Wise 1995; Henry et al. 1998), but the contribution of $\mathrm{D}_{3}$ receptors to this phenomenon is not known.

\section{MATERIALS AND METHODS}

\section{Mice}

Dopamine $\mathrm{D}_{3}$ receptor mutant mice were obtained by homologous recombination (Accili et al. 1996). To establish the colony at the INSERM U.339 (Hôpital SaintAntoine, Paris), a C57BL/6J x 129Sv $\mathrm{D}_{3}$ receptor deficient $\left(\mathrm{D}_{3}-/-\right)$ male mouse was backcrossed once with C57BL/6J females. Subsequent generations were derived from heterozygous intermatings. The genotype at the $\mathrm{D}_{3}$ receptor locus was determined by reverse transcription-polymerase chain reaction of tail RNA. Homozygous $\left(\mathrm{D}_{3}-/-\right)$ and heterozygous $\left(\mathrm{D}_{3}+/-\right) \mathrm{D}_{3}$ receptor mutant mice and their wild-type $\left(\mathrm{D}_{3}+/+\right)$ littermates were used for the experiments.

Animals were maintained under a $12 \mathrm{~h}$ light-dark cycle (lights on at 8:00), with food and water available $a d$ libitum, except during behavioral testing. They were housed in same-sex groups of 4-6 per cage and used at 10-12 weeks of age. All experiments were performed in 
accordance with the European Communities Council Directive for the care and use of laboratory animals.

\section{Drug Treatments}

In the first experiment, mice received a single, acute intraperitoneal (i.p.) injection of cocaine hydrochloride, 30 $\mathrm{mg} / \mathrm{kg}$, calculated as the free base (Coopération Pharmaceutique Française, Melun, France); $d l$-amphetamine sulfate, $10 \mathrm{mg} / \mathrm{kg}$ (Sigma); or haloperidol, $1 \mathrm{mg} / \mathrm{kg}$ (injectable solution; Janssen-Cilag). Control mice were injected with saline in a volume of $1 \mathrm{ml} / 100 \mathrm{~g}$ body weight. After evaluation of the acute behavioral response to psychostimulants and haloperidol, mice were killed by decapitation $3 \mathrm{~h}$ after the injection; the brains were rapidly removed, frozen on dry ice and stored at $-80^{\circ} \mathrm{C}$. In the second experiment, mice were injected with cocaine (20 $\mathrm{mg} / \mathrm{kg}$, i.p.) or saline once a day for seven days, their behavioral response was evaluated on Days 1 and 7 and they were killed $3 \mathrm{~h}$ after the last injection.

\section{Behavioral Testing}

In the first experiment, locomotor activity was measured in Plexiglas cages $(41 \times 28 \times 18 \mathrm{~cm})$ placed inside frames equipped with infrared photobeam cells, $2 \mathrm{~cm}$ above the floor (Opto-varimex mini; Columbus Instruments, Columbus, Ohio, USA). The number of beam breaks was recorded automatically by a computer with Opto-varimex software. Activity boxes were placed in a quiet room and $\mathrm{D}_{3}+/+, \mathrm{D}_{3}+/-$, and $\mathrm{D}_{3}-/-$ mice were analyzed at the same time. Basal activity levels were evaluated during 3-hour sessions during the light (10:00-13:00) and dark (21:00-24:00) phases of the circadian cycle in separate groups of mice.

The motor-stimulating effects of acute cocaine were tested one week later during the light phase. Mice were placed in the activity cages for a 2-hour habituation period, then injected with cocaine $(30 \mathrm{mg} / \mathrm{kg}$, i.p.) or saline, and replaced in the cages for an additional $3 \mathrm{~h}$.

Catalepsy testing was conducted $1 \mathrm{~h}$ following injection with haloperidol ( $1 \mathrm{mg} / \mathrm{kg}$, i.p.). The degree of catalepsy was measured by placing both forepaws on a horizontal wooden bar $(0.7 \mathrm{~cm}$ in diameter), $4 \mathrm{~cm}$ above the tabletop. The time in seconds until the mouse removed both forepaws from the bar was recorded, with a maximum cut-off time of $5 \mathrm{~min}$.

In the second experiment, mice were tested after the first and the last of seven daily injections of cocaine (20 $\mathrm{mg} / \mathrm{kg}$, i.p.) or saline, to evaluate the development of behavioral sensitization. On days 2-6, mice received daily injections of cocaine or saline in the home cage. On the days of behavioral testing, mice were placed in Plexiglas testing boxes (area: $30 \times 20 \mathrm{~cm}$ ) for $1 \mathrm{~h}$ of habituation. They were then injected with cocaine or saline and their behavior was recorded for $2 \mathrm{~h}$, using a videocamera attached to the ceiling. Horizontal activity (distance moved expressed in $\mathrm{m}$ ) was measured automatically from the videotapes with a motion analysis system, Ethovision (Noldus Information Technology, Wageningen, The Netherlands), and expressed as total values for each 10-minute interval.

Stereotyped behaviors were assessed with a behavioral scale described by MacLennan and Maier (1983), after the first and the last of seven daily cocaine injections. The behavioral rating was performed by an investigator unaware of the genotype and drug treatment of the animals. Mice were rated for 30 -sec periods starting $5 \mathrm{~min}$ after cocaine injection, and continuing every $5 \mathrm{~min}$ for $1 \mathrm{~h}$ using the following scale: 0 , inactive; 1 , intermittent activity; 2 , continuous activity; 3 , rearing; 4, intermittent stereotypic sniffing, repetitive head movements, or both, with periods of nonstereotypic behavior longer than 2 sec; 5, intermittent stereotypic sniffing, repetitive head movements, or both, with periods of nonstereotypic behavior shorter than 2 sec; 6 , continuous stereotypic sniffing; repetitive head movements, or both; and 7, continuous and restricted stereotypic sniffing, repetitive head movements, or both.

\section{In Situ Hybridization Histochemistry}

Coronal brain sections $(20 \mu \mathrm{m})$ were cut on a cryostat, thaw-mounted on Superfrost plus slides (Menzel-Glaser) and stored at $-20^{\circ} \mathrm{C}$ until used. The level of NT mRNA was assessed by in situ hybridization using ${ }^{35} \mathrm{~S}$ labeled oligonucleotide probes. To increase the intensity of the hybridization signal, we used a mixture of two oligonucleotide probes, complementary to nucleotides $272-319$ and $338-372$ of the rat NT gene (Kislauskis et al. 1988). In addition, we used two probes complementary to the mouse NT gene, from a partial clone published in the GenBank EST Division database (accession no. AA184803). The rat and mouse oligonucleotides yielded identical patterns of hybridization signal. Oligonucleotides were synthesized by Life Technologies. The probe was labeled at the $3^{\prime}$ end with ${ }^{35} \mathrm{~S}-\mathrm{ATP}$ (specific activity: $>1000 \mathrm{Ci} / \mathrm{mmol}$; Amersham) using terminal transferase (Boehringer-Mannheim).

The sections were warmed at room temperature, fixed with $4 \%$ paraformaldehyde in phosphate-buffered saline, $\mathrm{pH} 7.4$, acetylated in a solution of $4 \times$ standard saline citrate (SSC; $1 \times$ SSC: $0.15 \mathrm{M} \mathrm{NaCl}$ and $0.015 \mathrm{M}$ sodium citrate) containing $0.25 \%$ acetic anhydride and $0.1 \mathrm{M}$ triethanolamine, $\mathrm{pH} 8$, dehydrated in ascending concentrations of ethanol, delipidated in chloroform, rehydrated in $95 \%$ ethanol and allowed to dry. The hybridization medium ( $50 \%$ formamide, $4 \times$ SSC, $1 \%$ sarcosyl, $0.1 \mathrm{M}$ potassium phosphate $\mathrm{pH} 7.4,250 \mu \mathrm{g} / \mathrm{ml}$ yeast tRNA, $250 \mu \mathrm{g} / \mathrm{ml}$ herring sperm DNA, $10 \%$ dextran sulfate, $1 \times$ Denhardt's solution, $50 \mu \mathrm{g} / \mathrm{ml}$ polyA, and $10 \mathrm{mM}$ dithiothreitol), containing $0.5 \mathrm{pmol} / \mathrm{ml}$ of each oligonu- 
cleotide probe $\left(1-1.2 \times 10^{7} \mathrm{cpm} / \mathrm{ml}\right)$, was applied onto each slide and sealed under a coverslip. Hybridization was allowed to proceed overnight at $42^{\circ} \mathrm{C}$ in humidified boxes. Coverslips were removed in $4 \times$ SSC and the sections were rinsed at $42^{\circ} \mathrm{C}$ in decreasing concentrations of SSC for $30 \mathrm{~min}$ each time (once in $4 \times$ SSC with $0.02 \%$ sodium dodecyl sulfate, twice in $1 \times$ SSC and twice in $0.1 \times$ SSC), dehydrated and allowed to dry. Film autoradiograms were obtained by apposition of radiolabeled sections to Hyperfilm $\beta \max$ (Amersham) for one month at room temperature. The films were developed in Kodak D-19 developer and fixed in Kodak Unifix.

\section{Analysis of Hybridization Signal}

Quantitative optical density measurements were carried out using a computer-based image analysis system, HISTO-RAG (Biocom, Les Ulis, France). The optical density of the background (measured in the parietal cortex, a region that does not contain NT mRNA) was determined in each tissue section and subtracted from all values. Optical density values were expressed as $\mathrm{nCi} / \mathrm{mg}$ tissue using ${ }^{14} \mathrm{C}$ standards, exposed together with the hybridized tissue. Brain structures were identified according to the atlas of Franklin and Paxinos (1997). Hybridization signal was analyzed at two striatal levels, shown in Figure 1: rostral (0.98 $\mathrm{mm}$ anterior to bregma) and caudal ( $-0.10 \mathrm{~mm}$ posterior to bregma). The following regions were analyzed at the rostral level: nucleus accumbens shell and core, olfactory tubercle, lateral septum and dorsolateral, dorsomedial and ventrolateral striatum. At the caudal level, measurements were performed in the dorsolateral, dorsomedial, and ventrolateral striatum. The analysis was performed bilaterally on at least six brain sections per animal at each level.

\section{Statistics}

In situ hybridization results from each brain region were evaluated with analyses of variance (ANOVA), with two between subjects factors (treatment and genotype), followed when indicated by a Tukey test for multiple comparisons to establish significant differences between the means. Behavioral data were analyzed using a two-way ANOVA for repeated measures over time.

\section{RESULTS}

\section{Basal Expression of NT mRNA}

The distribution of NT mRNA expression in vehicleinjected mice was restricted rostrally to the nucleus accumbens shell, the olfactory tubercle and the lateral septum (Figure 2), in agreement with studies in the rat (Alexander et al. 1989; Merchant and Dorsa 1993; Betan-
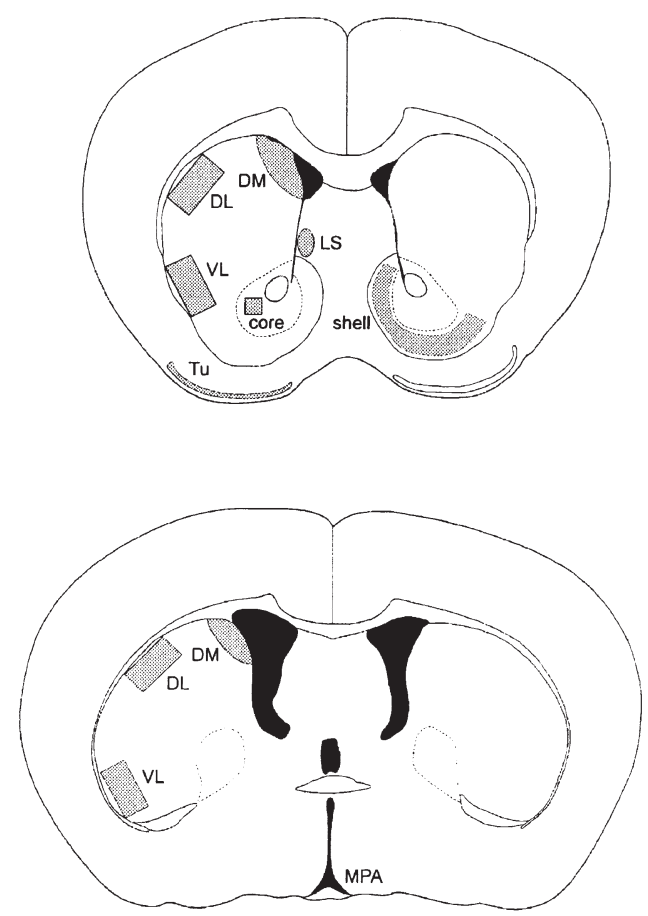

Figure 1. Schematic representation of the forebrain regions where NT mRNA hybridization signal was measured at the rostral (bregma $0.98 \mathrm{~mm}$, top) and caudal (bregma -0.10 $\mathrm{mm}$, bottom) striatal level of the mouse brain. DL, dorsolateral striatum; DM, dorsomedial striatum; MPA, medial preoptic area; VL, ventrolateral striatum; LS, lateral septum; Tu, olfactory tubercle.

cur et al. 1997). Labeling in the nucleus accumbens shell was irregular, with intensely labeled cell clusters scattered within the region. The signal was more prominent in the lateral part of the shell than in the medial region. The caudate putamen expressed very low levels of NT mRNA, except in the dorsomedial region of the caudal striatum, where a strong labeling was observed in the periventricular area, beneath the corpus callosum. At the caudal level, an intense hybridization signal was present in the medial preoptic area. No significant differences in basal levels of NT mRNA expression were observed among $D_{3}-/-, D_{3}+/-$ and $D_{3}+/+$ mice in any of the brain regions studied (Table 1 ).

\section{Effect of Acute Administration of Haloperidol on NT mRNA Expression}

Analysis of film autoradiograms showed that acute administration of haloperidol induced a marked increase in NT gene expression in the dorsolateral, dorsomedial and ventrolateral striatum in wild-type mice and $\mathrm{D}_{3}-/-$ and $\mathrm{D}_{3}+/$ - mutants, both at rostral and caudal levels, compared to vehicle-injected animals (Figures 2 and 3). This up-regulation was stronger in the dorsolateral and 


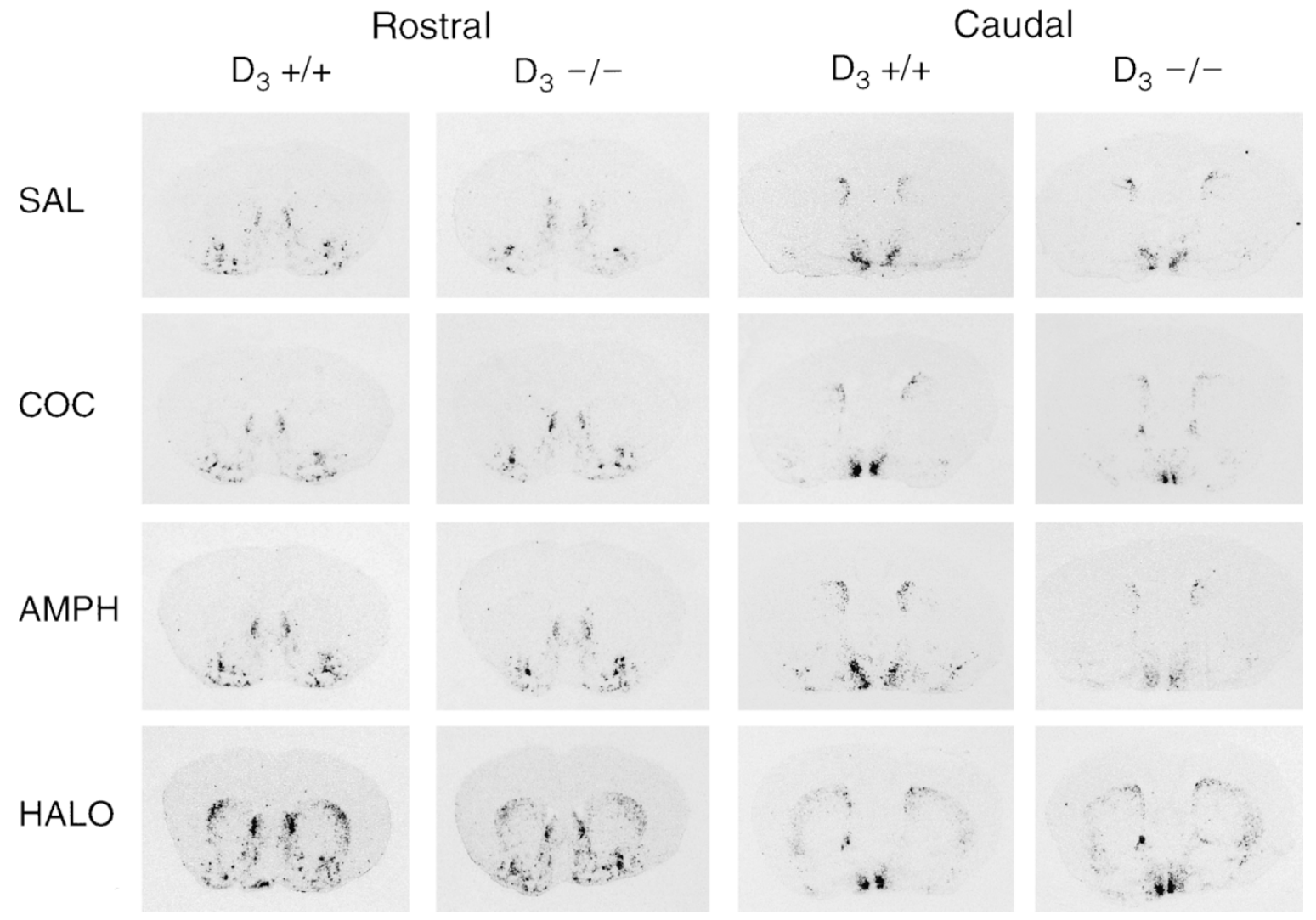

Figure 2. In situ hybridization of NT mRNA after an acute injection of saline, cocaine, amphetamine, or haloperidol in $\mathrm{D}_{3}+/+$ and $\mathrm{D}_{3}-/-$ mice. Mice were injected i.p. with a single dose of saline (SAL), cocaine (COC, $\left.30 \mathrm{mg} / \mathrm{kg}\right)$, amphetamine $(\mathrm{AMPH}, 10 \mathrm{mg} / \mathrm{kg}$ ), or haloperidol (HALO, $1 \mathrm{mg} / \mathrm{kg}$ ), and killed $3 \mathrm{~h}$ after. Film autoradiograms show NT mRNA expression in coronal brain sections at the rostral and caudal striatal level.

ventrolateral striatum $(\sim 800 \%)$ than in the dorsomedial area $(120 \%)$. The magnitude of the increases in NT mRNA expression did not differ among the genotypes. Acute administration of haloperidol did not increase NT gene transcription in the shell of the nucleus accumbens in any of the three genotypes (Figure 3).

\section{Effects of Acute Administration of Cocaine and Amphetamine on NT mRNA Expression}

As shown in Figure 3, acute administration of cocaine or amphetamine increased NT mRNA levels in the shell of the nucleus accumbens and in the olfactory tubercle. Cocaine also enhanced NT gene expression in the dor-

Table 1. Basal NT mRNA Expression in $\mathrm{D}_{3}+/+, \mathrm{D}_{3}+/-$, and $\mathrm{D}_{3}-/-$ Mice

\begin{tabular}{lrrr}
\hline Brain Regions & \multicolumn{1}{c}{$\mathbf{D}_{3}+l+$} & $\mathbf{D}_{3}+I-$ & $\mathbf{D}_{3}-I-$ \\
\hline Nucleus accumbens, core & $1.44 \pm 0.26$ & $1.74 \pm 0.35$ & $1.27 \pm 0.19$ \\
Nucleus accumbens, medial shell & $5.66 \pm 0.62$ & $6.39 \pm 0.73$ & $7.71 \pm 0.60$ \\
Nucleus accumbens, lateral shell & $18.87 \pm 3.23$ & $16.22 \pm 1.30$ & $18.88 \pm 3.37$ \\
Olfactory tubercle & $13.47 \pm 1.90$ & $10.00 \pm 1.16$ & $12.08 \pm 1.32$ \\
Lateral septum & $19.63 \pm 1.62$ & $22.49 \pm 2.20$ & $21.39 \pm 1.95$ \\
Dorsomedial striatum, rostral & $1.76 \pm 0.30$ & $2.11 \pm 0.34$ & $1.87 \pm 0.24$ \\
Dorsomedial striatum, caudal & $6.58 \pm 2.61$ & $6.73 \pm 1.95$ & $8.62 \pm 2.76$ \\
Dorsolateral striatum, rostral & $1.75 \pm 0.16$ & $1.86 \pm 0.30$ & $1.49 \pm 0.16$ \\
Dorsolateral striatum, caudal & $0.52 \pm 0.18$ & $0.69 \pm 0.13$ & $0.64 \pm 0.11$ \\
Ventrolateral striatum, rostral & $1.96 \pm 0.42$ & $1.79 \pm 0.37$ & $1.38 \pm 0.22$ \\
Ventrolateral striatum, caudal & $1.36 \pm 0.25$ & $1.33 \pm 0.20$ & $1.09 \pm 0.16$ \\
\hline
\end{tabular}

In situ hybridization autoradiograms from vehicle-treated mice from the first experiment (shown in Figures 2 and 3) were quantified with a computer-assisted image analysis system at rostral (bregma $0.98 \mathrm{~mm}$ ) and caudal (bregma $-0.10 \mathrm{~mm}$ ) levels. Results are expressed as $\mathrm{nCi} / \mathrm{mg}$ tissue (mean $\pm \mathrm{SEM}$ ); $n=4-7$ mice per group. There were no significant differences in basal NT mRNA expression among $\mathrm{D}_{3}-/-, \mathrm{D}_{3}+/-$, and wild-type mice in any of the regions studied. 

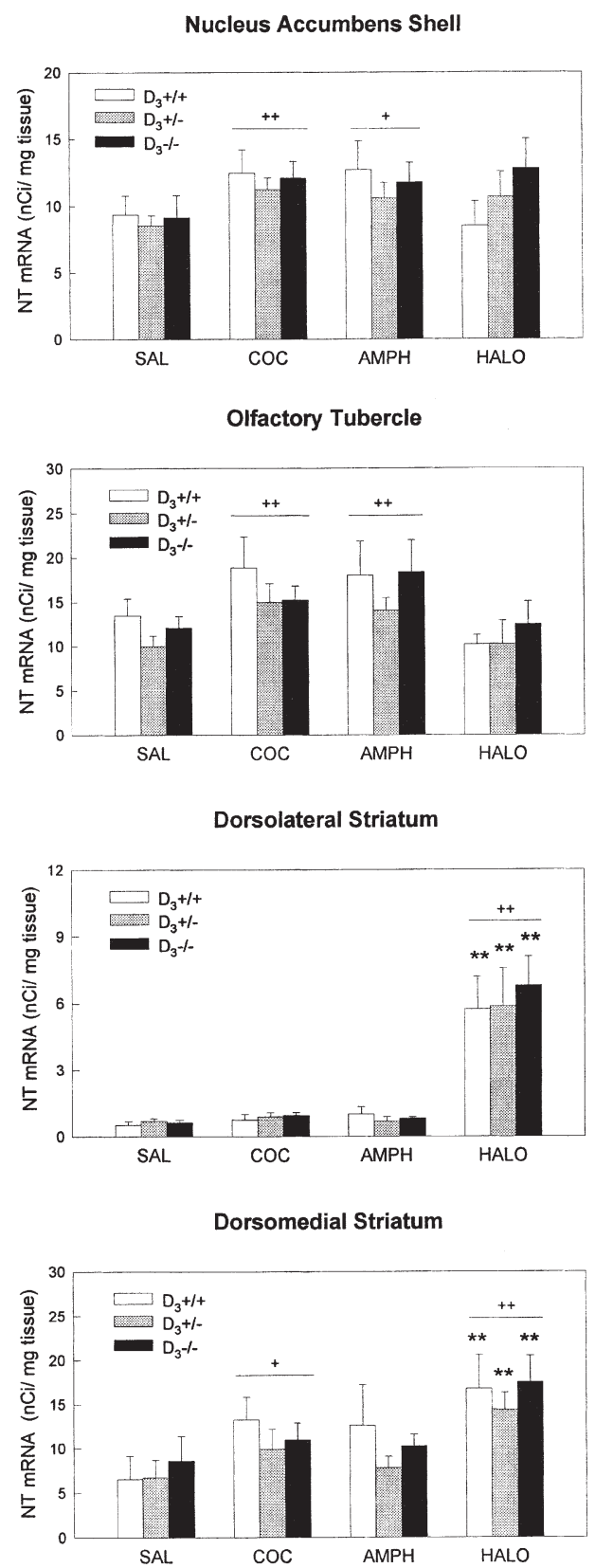

Ventrolateral Striatum

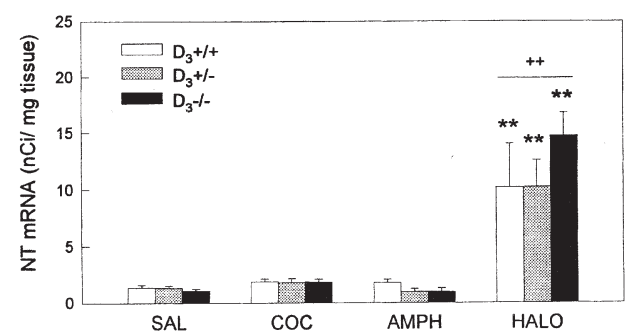

Figure 3. Quantification of NT mRNA in situ hybridization autoradiograms after an acute injection of saline, cocaine, amphetamine, or haloperidol in $\mathrm{D}_{3}+/+, \mathrm{D}_{3}+/-$ and $\mathrm{D}_{3}-/-$ mice. Films were analyzed with a computer-assisted image analysis system and results expressed as $\mathrm{nCi} / \mathrm{mg}$ tissue; bars represent mean + SEM $(n=4-7$ mice per group). NT somedial region of the striatum, both at rostral and caudal levels. However, the magnitude of these increases (30-40\% in the nucleus accumbens and olfactory tubercle, and $35-55 \%$ in the striatum) was lower than that observed in the caudate putamen after haloperidol. Thus, the effects of cocaine and amphetamine on NT mRNA expression were significant only as a treatment effect (ANOVA, cocaine or amphetamine vs. saline-treated mice, irrespective of genotype), but not when mice of each genotype were analyzed separately.

\section{Effect of Repeated Administration of Cocaine on NT mRNA Expression}

Three hours after the last of seven daily injections of cocaine, a marked increase in NT mRNA expression was observed in a restricted population of neurons in the dorsomedial striatum at the caudal level in wild-type animals (Figures 4 and 5A). In contrast, the same repeated administration of cocaine failed to increase NT mRNA levels in the caudate putamen of $\mathrm{D}_{3}-/-$ and $\mathrm{D}_{3}+/-$ mice. Repeated cocaine did not modify NT gene transcription in the rostral striatum (Figure 5B), nucleus accumbens shell and core (Figure 5C), olfactory tubercle (Figure 5C), or lateral septum (data not shown) of wild-type or $\mathrm{D}_{3}$ receptor mutant mice.

\section{Behavioral Analysis}

Contradictory results have been reported concerning the presence of a transient increase in spontaneous locomotor activity during the initial ( 5 or $15 \mathrm{~min}$ ) exploration of a novel environment in $D_{3}$ receptor deficient mice (Accili et al. 1996; Xu et al. 1997; Boulay et al. 1999). Our results indicate that basal activity levels in wild-type and mutant mice were similar during the light period of the light/dark cycle (Figure 6A). However, $\mathrm{D}_{3}-/-$ mice were markedly hyperactive during the dark period (Figure 6A), when the dopaminergic system is physiologically activated in nocturnal animals such as rodents. This hyperactivity was observed from the beginning of the test session and persisted for the whole testing period $(3 \mathrm{~h})$. The locomotor activity of $D_{3}-/-$ and $D_{3}+/-$ mice was significantly enhanced during the night cycle compared to the day cycle, whereas the increase during the dark cycle observed in wild-type animals was not statistically significant (Figure 6A). As shown in Figure 6B, acute cocaine (30 mg/ $\mathrm{kg}$ ) stimulated locomotor activity to a similar extent in

gene expression in the striatum is shown here at the caudal level. Results were analyzed by ANOVA followed by Tukey test. Significant main effects of treatment (vs. saline-treated mice) are indicated by ${ }^{+}(p<.05)$, and ${ }^{+}+(p<.01) .{ }^{* *} p<.01$, vs. saline-treated mice of the same genotype. 


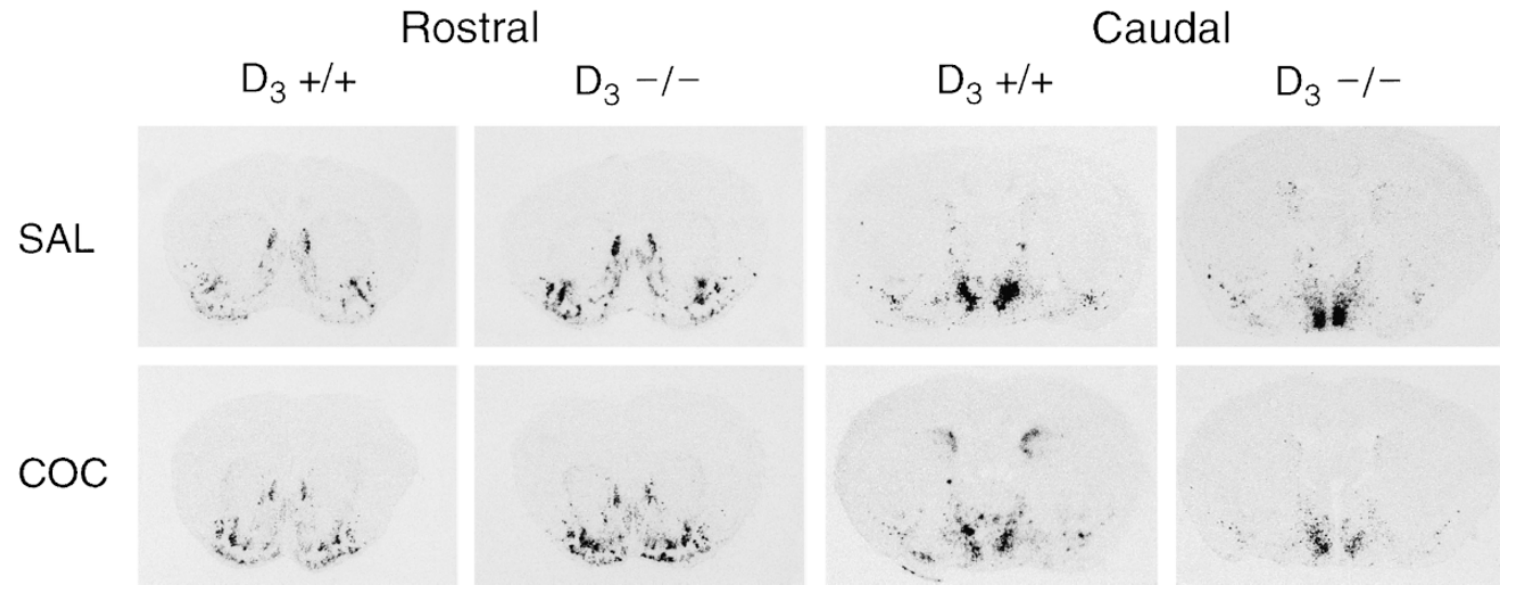

Figure 4. In situ hybridization of NT mRNA after repeated cocaine administration in $\mathrm{D}_{3}+/+$ and $\mathrm{D}_{3}-/-$ mice. Mice were injected once a day for seven days with saline (SAL) or cocaine (COC, $20 \mathrm{mg} / \mathrm{kg}$ i.p.) and killed $3 \mathrm{~h}$ after the last injection. Typical film autoradiograms from saline- and cocaine-injected mice are shown at the rostral and caudal striatal level.

the three groups of mice. Moreover, no differences were observed among $\mathrm{D}_{3}-/-, \mathrm{D}_{3}+/-$, and $\mathrm{D}_{3}+/+$ mice in haloperidol-induced catalepsy (Figure 6C).

In the second experiment, mice received seven daily cocaine injections $(20 \mathrm{mg} / \mathrm{kg})$ and their behavioral response was evaluated on the first and the last cocaine challenges to assess the development of behavioral sensitization. On Day 1, cocaine significantly enhanced locomotor activity in the three groups of mice, although the response of $D_{3}+/-$ and $D_{3}-/-$ mice was lower than that of wild-type mice (Figure 7A). The locomotor response to cocaine on Day 7 was similar in the three genotypes. Wild-type and $\mathrm{D}_{3}$ receptor deficient mice failed to show an increment in cocaine-induced locomotor hyperactivity after daily injections of the psychostimulant compared to Day 1 (Figure 7A). However, as shown in Figure 7B, repeated exposure to cocaine induced an increase in stereotypes such as repetitive sniffing and head bobbing in wild-type and mutant mice, indicating the development of behavioral sensitization. Stereotypies after repeated cocaine were quantitatively and qualitatively similar in $\mathrm{D}_{3}-/-, \mathrm{D}_{3}+/-$, and $\mathrm{D}_{3}+/+$ mice.

\section{DISCUSSION}

Mice lacking functional dopamine $\mathrm{D}_{3}$ receptors were used to examine the role of $\mathrm{D}_{3}$ receptors in the transcription of the NT gene using in situ hybridization. There was no modification in the expression pattern of NT mRNA in $\mathrm{D}_{3}$ receptor deficient mice under basal conditions. Acute treatment with haloperidol dramatically up-regulated NT mRNA levels in the striatum of wildtype and mutant mice. Acute administration of cocaine or amphetamine resulted in smaller increases in NT
mRNA expression in the nucleus accumbens shell and olfactory tubercle, which were observed in mice regardless of their genotype. In contrast, repeated administration of cocaine enhanced NT gene expression in neurons confined to the dorsomedial striatum in wild-type mice, but failed to affect NT mRNA levels in $\mathrm{D}_{3}-/-$ and $\mathrm{D}_{3}+/-$ mice. These findings suggest that $\mathrm{D}_{3}$ receptors are not necessary for the induction of NT mRNA by acute administration of psychostimulants or haloperidol, but appear to be implicated in striatal NT gene regulation after repeated cocaine. The behavioral analysis demonstrated that $\mathrm{D}_{3}$ mutant mice exhibited increased locomotor activity only during the dark phase of the circadian cycle, but did not differ from wild-type littermates in the locomotor response to acute cocaine and the development of behavioral sensitization.

\section{$D_{3}$ Receptors Do Not Regulate Basal NT mRNA Expression}

Our results showed normal basal expression of NT mRNA in the forebrain of $D_{3}$ receptor deficient mice, suggesting that $\mathrm{D}_{3}$ receptors do not exert a regulatory control on the transcription of the gene encoding NT. These data contradict a recent report in the rat showing that antisense oligodeoxynucleotides directed against $\mathrm{D}_{3}$ receptors decrease basal NT mRNA expression in the shell of the nucleus accumbens (Tremblay et al. 1997). There may be several reasons for this discrepancy, including species-related differences or compensatory mechanisms in $\mathrm{D}_{3}-/-$ mice during development. $\mathrm{D}_{3}$ mutant mice show normal number and affinity of $\mathrm{D}_{2}$ receptors (Accili et al. 1996; Xu et al. 1997; Jung et al. 1999), arguing against a compensatory role of $\mathrm{D}_{2}$ receptors. Although $\mathrm{D}_{3}$ deficient mice exhibit apparently normal dopaminergic systems, with normal levels 
Caudate Putamen, Caudal Level

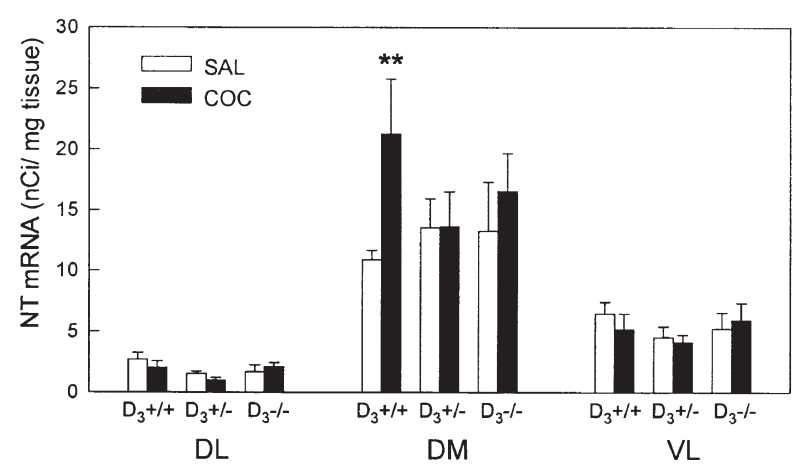

$\mathrm{B}$

Caudate Putamen, Rostral Level

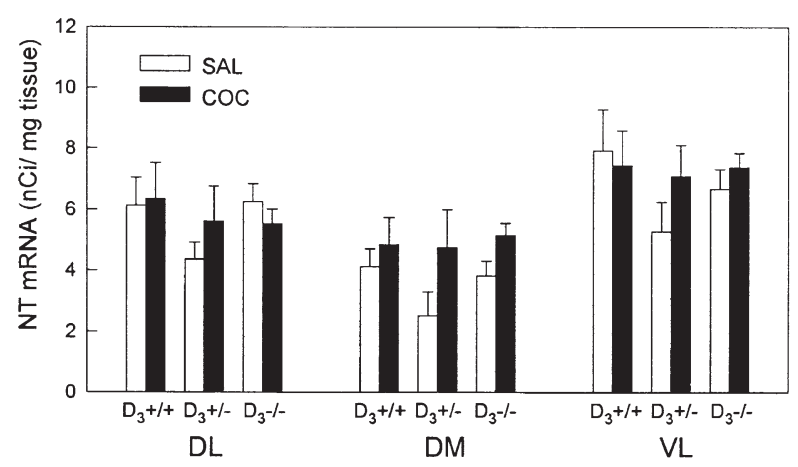

C Nucleus Accumbens and Olfactory Tubercle

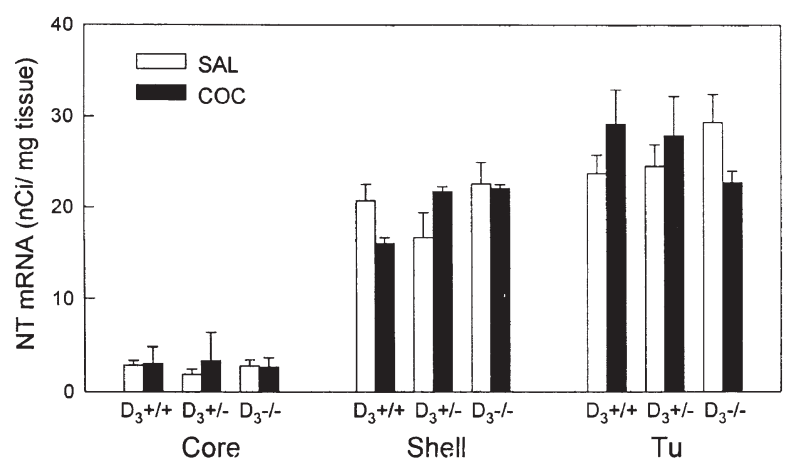

Figure 5. Quantification of NT mRNA in situ hybridization autoradiograms after repeated cocaine in $\mathrm{D}_{3}+/+, \mathrm{D}_{3}+/-$, and $\mathrm{D}_{3}-/-$ mice. Results are expressed as $\mathrm{nCi} / \mathrm{mg}$ tissue; bars represent mean + SEM $\left(n=5-7\right.$ mice per group). ${ }^{* *} p<$ .01 , vs. saline-treated wild-type mice, ANOVA followed by Tukey test. DL, dorsolateral striatum; DM, dorsomedial striatum; VL, ventrolateral striatum; Tu, olfactory tubercle.

of tyrosine hydroxylase, dopamine transporter, and $\mathrm{D}_{1}$ receptors (Accili et al. 1996; Xu et al. 1997), possible adaptive alterations at the second messenger level can not be excluded.

Koeltzow et al. (1998) reported that $\mathrm{D}_{3}-/-$ mice exhibit increased basal dopamine release in the nucleus accumbens. Although basal NT gene expression has been shown to be under tonic control by endogenous dopamine (Merchant et al. 1989), our results indicate that the increase in dopamine release in $\mathrm{D}_{3}-/-$ mice is not associated with altered NT mRNA expression, again suggesting the development of compensatory effects to counterbalance enhanced dopamine neurotransmission. In agreement with this hypothesis, previous studies in the rat have shown that repeated administration of amphetamine results in blunted NT mRNA responses in the nucleus accumbens shell to subsequent stimulation (Feldpausch et al. 1998).

\section{Haloperidol-Induced NT mRNA Expression and Catalepsy Are Unaltered in $\mathrm{D}_{3}$ Receptor Mutant Mice}

In these experiments, $\mathrm{D}_{3}$ receptor deficient mice were studied to examine the contribution of $\mathrm{D}_{3}$ receptors to the molecular (NT mRNA) and behavioral (catalepsy) effects produced by the typical antipsychotic agent haloperidol. Results showed that both the regional pattern of induction of NT mRNA by haloperidol, and the magnitude of the effects in the striatum were identical in $\mathrm{D}_{3}-/-$ and wild-type mice. Similarly, haloperidol remained effective in inducing catalepsy in $\mathrm{D}_{3}-/-$ mice, a behavioral response that has been correlated with the extrapyramidal motor side affects seen in humans following antipsychotic drug administration (Hoffman and Donovan 1995). These findings indicate that haloperidol-induced increase in NT mRNA expression and catalepsy can take place in the complete absence of $\mathrm{D}_{3}$ receptors. Haloperidol-induced NT gene expression is likely to be mediated by other members of the $\mathrm{D}_{2}$-class receptor family, most probably the $\mathrm{D}_{2}$ receptor itself.

Several lines of evidence suggest the involvement of $\mathrm{D}_{2}$ receptors in the effects of haloperidol on NT gene transcription. Basal release of dopamine exerts a tonic inhibitory control over NT systems by acting through $\mathrm{D}_{2}$ receptors. Specifically, blockade of $\mathrm{D}_{2}$ receptors by antipsychotic drugs or depletion of dopamine after 6OHDA lesion of the nigrostriatal pathway or treatment with reserpine, increase NT immunoreactivity in the striatum and nucleus accumbens (Merchant et al. 1989). Furthermore, administration of raclopride (Augood et al. 1991) and eticlopride (Sirinathsinghji et al. 1994), two $\mathrm{D}_{2}$ receptor antagonists, induce a regional pattern of NT mRNA expression that is indistinguishable from that produced by haloperidol. The majority of haloperidolsensitive NT mRNA-expressing neurons in the dorsal striatum also express enkephalin mRNA (Augood et al. 1997), and immunocytochemical (Yung et al. 1995) and in situ hybridization studies have shown that enkephalin-containing cells express preferentially $\mathrm{D}_{2}$ receptors as opposed to $\mathrm{D}_{1}$ receptors, thus indicating that haloperidol-sensitive NT neurons express $\mathrm{D}_{2}$ receptors. 


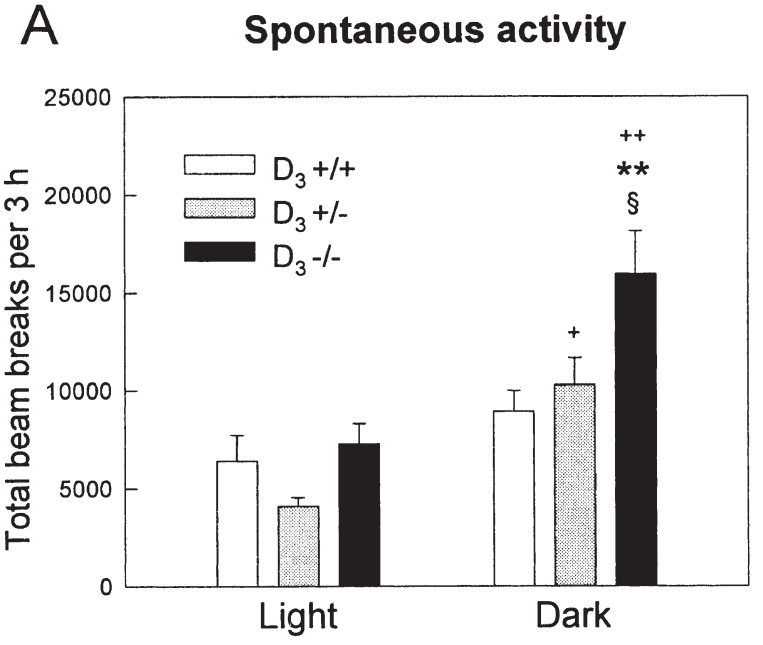

B Cocaine-induced locomotion

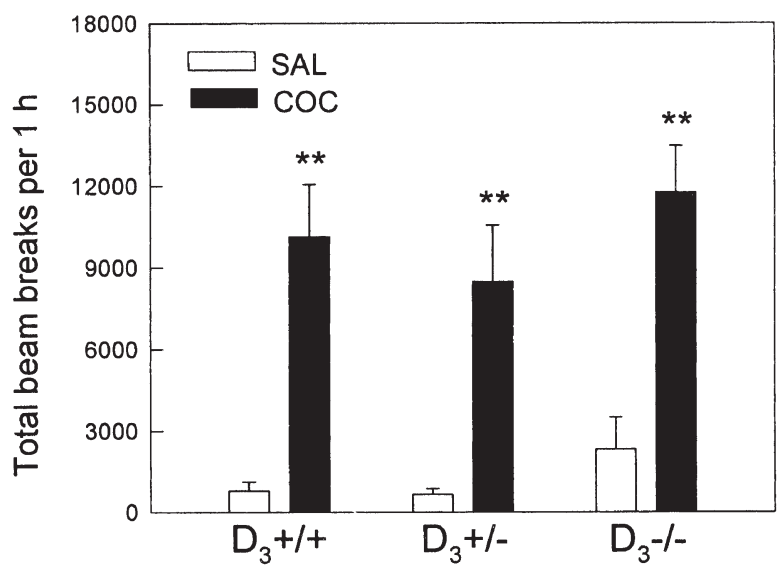

C Haloperidol-induced catalepsy

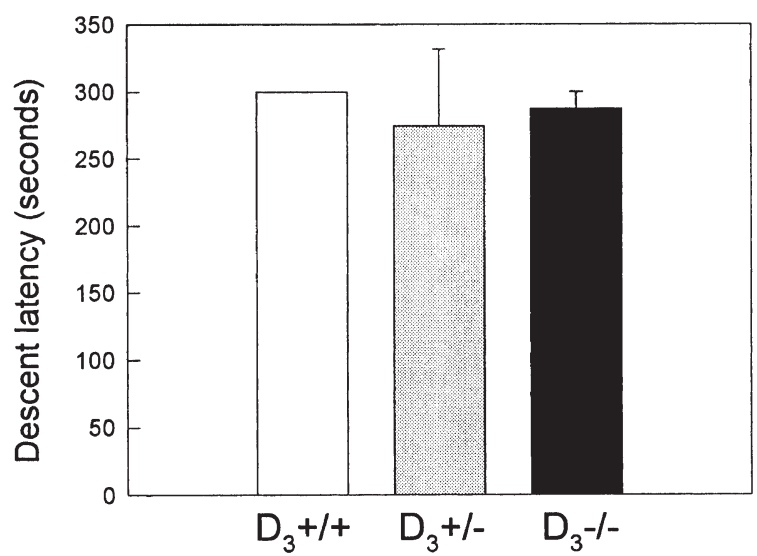

Figure 6. (A) Spontaneous locomotor activity of naive $\mathrm{D}_{3}+/+, \mathrm{D}_{3}+/-$, and $\mathrm{D}_{3}-/-$ mice during the light and dark periods of the circadian cycle. Locomotor activity was recorded for a period of $3 \mathrm{~h}$ during the light (10:00-13:00) or the dark (21:00-24:00) phase of the light-dark cycle. Values represent mean + SEM photocell beam interruptions for $3 \mathrm{~h}$
Blockade of $\mathrm{D}_{2}$-like receptors by haloperidol has been suggested to exert opposing roles in NT mRNA expression in the nucleus accumbens by acting through $\mathrm{D}_{3}$ or $\mathrm{D}_{2}$ receptors (Diaz et al. 1994; Lévesque et al. 1995). $D_{3}$ receptor mRNA is abundantly expressed in the ventromedial subdivision of the shell, where it is colocalized with NT mRNA in a large number of neurons (Diaz et al. 1994, 1995). According to these authors, blockade of $\mathrm{D}_{3}$ receptors by haloperidol decreases NT gene expression in this region, whereas blockade of $\mathrm{D}_{2}$ receptors increases NT mRNA expression in the $\mathrm{D}_{2}$ receptor-rich dorsal area of the medial shell (cone). Subregional analysis of NT mRNA expression in the accumbens shell in haloperidol-treated mice $(1 \mathrm{mg} / \mathrm{kg})$ showed no evidence of decreased NT gene transcripts in the ventromedial shell (not shown). Similarly, Merchant et al. (1996) failed to observe reduced NT mRNA levels in this region after administration of haloperidol to rats. This discrepancy could be due to the high doses of haloperidol employed in the studies by Diaz et al. (1994) and Lévesque et al. (1995), 20 and $5 \mathrm{mg} / \mathrm{kg}$, respectively, whereas we and Merchant et al. (1996) used $1 \mathrm{mg} / \mathrm{kg}$.

\section{Acute and Daily Cocaine Treatments Differentially Regulate NT mRNA Levels in Striatal Neurons in $D_{3}$ Receptor Deficient Mice}

Following acute treatment with cocaine or amphetamine, significant increases in NT gene expression occurred in the shell of the nucleus accumbens and olfactory tubercle. This effect did not differ between wildtype and $D_{3}$ receptor null mice, suggesting that $D_{3}$ receptors are not involved in NT gene induction in the ventral striatum by these indirect dopamine agonists. However, exposure to daily cocaine led to a significant increase in NT mRNA expression in the dorsomedial division of the caudal striatum in wild-type mice but

test sessions ( $n=11-15$ mice per group). $\mathrm{D}_{3}-/-$ mice were hyperactive during the dark phase compared to $\mathrm{D}_{3}+/+\left({ }^{* *} p<\right.$ .01, ANOVA followed by Tukey test) and $\mathrm{D}_{3}+/-$ mice $\left({ }^{\S} p<\right.$ .05). The locomotor activity of the $D_{3}-/-$ and $D_{3}+/-$ mice was significantly higher during the night cycle compared to the day cycle $\left({ }^{+} p<.05,{ }^{+}+p<.01\right)$. (B) Effect of acute cocaine on the locomotor activity of wild-type and $\mathrm{D}_{3}$ receptor deficient mice. Mice were injected with cocaine $(30 \mathrm{mg} /$ $\mathrm{kg}$, i.p.) or saline and locomotor activity was recorded $(n=$ 6-8 mice per group). Cocaine induced a significant increase in locomotion in the three groups of mice $\left({ }^{* *} p<.01\right.$ as compared to saline-treated mice of the same genotype). (C) Haloperidol-induced catalepsy in $\mathrm{D}_{3}+/+, \mathrm{D}_{3}+/-$, and $\mathrm{D}_{3}-/-$ mice. Catalepsy was assessed $1 \mathrm{~h}$ after administration of haloperidol $(1 \mathrm{mg} / \mathrm{kg}$, i.p.), using the bar test. Values represent mean + SEM descent latency (time in seconds to remove both forepaws from the bar) during a 5-min test $(n=$ 4-5 mice per group). 

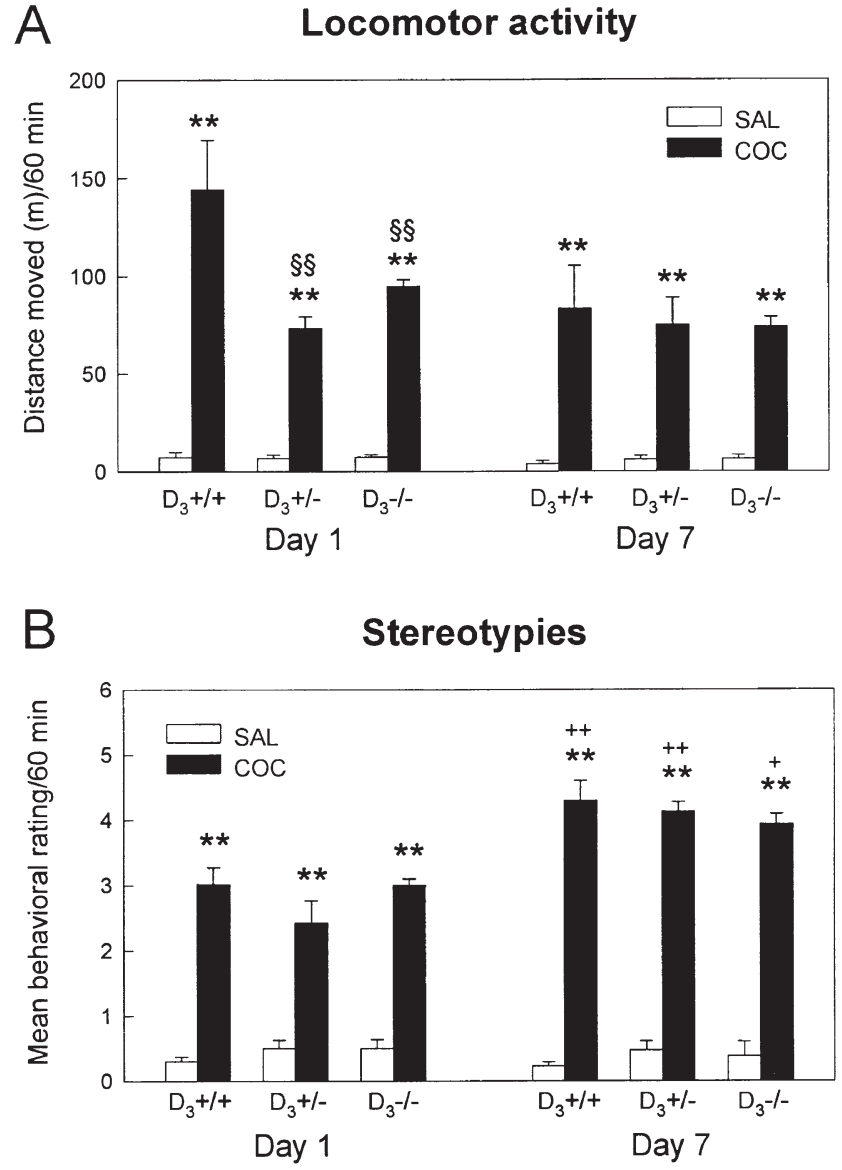

Figure 7. Effect of acute and repeated cocaine on the locomotor activity (A) and stereotyped behavior (B) of $\mathrm{D}_{3}+/+$, $\mathrm{D}_{3}+/-$, and $\mathrm{D}_{3}-/-$ mice. Animals received seven daily injections of cocaine $(20 \mathrm{mg} / \mathrm{kg}$, i.p.) or saline, and their behavioral response was recorded on the first (Day 1) and the last (Day 7) injections. (A) Locomotor activity is expressed as mean \pm SEM total distance moved $(\mathrm{m})$ during the first hour after the injection ( $n=6-8$ mice per group). Cocaine increased locomotion in the three groups of mice on Days 1 and $7{ }^{* *} p<.01$ as compared to saline-treated mice of the same genotype, ANOVA followed by Tukey test), although $D_{3}+/-$ and $D_{3}-/-$ mice showed lower activity compared to wild-type animals ( $\$ \S_{p}<.01$, Tukey test). No increase in horizontal locomotion (behavioral sensitization) was observed in wild-type or mutant mice on Day 7 when compared to Day 1. (B) Values represent mean \pm SEM behavioral rating during the first hour after the injection. Cocaine-treated mice had a higher behavioral rating than saline-treated animals on Days 1 and $7\left(^{* *} p<.01\right.$ as compared to saline-treated mice of the same genotype). The increased behavioral rating on Day 7 indicates the development of behavioral sensitization, characterized by the appearance of stereotypes (repetitive sniffing and head bobbing) in animals exposed repeatedly to the psychostimulant $\left({ }^{+} p<.05,{ }^{++} p<.01\right.$ as compared to mice of the same genotype on Day 1). did not alter NT gene expression in $\mathrm{D}_{3}-/-$ and $\mathrm{D}_{3}+/-$ mice. Interestingly, the highest amounts of $\mathrm{D}_{3}$ receptor binding sites and mRNA in the striatum in the rat and mouse have been detected in the dorsomedial region (Sokoloff et al. 1990; Levant et al. 1993; Bordet et al. 1997; Levant 1998). Taken together, these findings suggest that $\mathrm{D}_{3}$ receptors in dorsomedial striatal neurons could be involved in the regulation of NT gene expression after repeated psychostimulant administration. Alternatively, the increase in NT gene transcription by cocaine in this region could be modulated via $\mathrm{D}_{3}$ receptors located in a distant site. One possibility may be the substantia nigra, where expression of $D_{3}$ receptors in dopamine neurons has been reported (Diaz et al. 1995).

The effects of cocaine and amphetamine on NT concentration and gene expression in striatal and accumbal systems involve activation of $D_{1}$ receptors, since these effects are blocked by co-administration of the $\mathrm{D}_{1}$-selective antagonist, SCH 23390 (Merchant et al. 1988; Hanson et al. 1989; Castel et al. 1993). In the ventromedial shell subdivision of the nucleus accumbens, $60 \%$ of NT neurons express $D_{3}$ receptor mRNA (Diaz et al. 1995), and $D_{1}$ and $D_{3}$ receptors in this region are coexpressed to a significant extent (Ridray et al. 1998). In spite of this colocalization, $\mathrm{D}_{3}$ receptors do not appear to participate in the $\mathrm{D}_{1}$-mediated regulation of NT mRNA by psychostimulants. Similarly, $\mathrm{D}_{1}$ receptor agonist activation of c-fos expression in the ventromedial shell was not affected by $\mathrm{D}_{3}$ receptor activation (Ridray et al. 1998). However, a recent study using $\mathrm{D}_{3}$ receptor deficient mice showed that $D_{3}$ receptors play a facilitatory role in the regulation of $c-f o s$ responses to $D_{1}$ agonist stimulation (Jung and Schmauss 1999). Thus, functional interactions between $D_{3}$ and $D_{1}$ receptors appear to be complex and vary depending on the brain region and the gene studied.

\section{$D_{3}$ Receptor Mutant Mice Exhibit Normal Cocaine- Induced Behavioral Sensitization}

Cocaine produces a rapid, dose-dependent increase in extracellular concentrations of dopamine in the nucleus accumbens and caudate-putamen, regions that appear to be involved in locomotion and stereotypy, respectively. Investigation of the behavioral effects of acute cocaine $(30 \mathrm{mg} / \mathrm{kg})$ in $\mathrm{D}_{3}$ receptor deficient mice revealed that the drug stimulated locomotor activity to a similar extent in $\mathrm{D}_{3}-/-$ and wild-type mice. This result is consistent with a previous study in $\mathrm{D}_{3}$ mutant mice (Xu et al. 1997) showing increased behavioral sensitivity to the effects of cocaine only after a low dose of the drug $(5 \mathrm{mg} / \mathrm{kg})$, whereas no differences were observed at higher doses $(10-40 \mathrm{mg} / \mathrm{kg})$.

Our results show that after repeated administration of cocaine, wild-type and $\mathrm{D}_{3}$ mutant mice exhibited a 
similar behavioral sensitization to the effects of the drug. The three groups of mice showed increased stereotypies such as sniffing and repetitive head movements on the last cocaine challenge. Repeated exposure to cocaine failed to induce an increment in locomotor hyperactivity in wild-type and $D_{3}$ receptor deficient mice, which could be explained by the appearance of stereotyped behaviors. Our results using $\mathrm{D}_{3}$ receptor mutant mice suggest that $D_{3}$ receptors are not required for the expression of psychostimulant-induced behavioral sensitization.

The mesolimbic system, and the nucleus accumbens in particular, is considered the main neural substrate for the rewarding and locomotor activating properties of psychostimulants (Self and Nestler 1995; Koob 1992). Thus, the limbic distribution of $\mathrm{D}_{3}$ receptors suggests that they may play an important role in drug abuse. In support of this hypothesis, the number of $D_{3}$ receptors has been reported to be up-regulated in the nucleus accumbens of cocaine-overdose victims (Staley and Mash 1996; Segal et al. 1997). Moreover, $\mathrm{D}_{3}$ receptors have been implicated in the development of psychostimulant-induced behavioral sensitization. Repeated cocaine has been reported to induce a significant dose-dependent increase in striatal $D_{3}$ receptors in behaviorally sensitized rats, whereas $\mathrm{D}_{3}$ receptors in the nucleus accumbens are reduced (Wallace et al. 1996). Similarly, increased expression of striatal $\mathrm{D}_{3}$ receptors has been proposed as the mechanism responsible for the development of sensitization to repeated administration of levodopa (Bordet et al. 1997). However, a similar increase in $D_{3}$ receptors was not observed during cocaine-induced sensitization in the present study. Indeed, in $\mathrm{D}_{3}+/+$ mice, repeated exposure to cocaine did not result in increased expression of $\mathrm{D}_{3}$ receptors in the nucleus accumbens or caudate putamen, as assessed by $\left[{ }^{3} \mathrm{H}\right]-7-$ OH-DPAT autoradiography (data not shown).

\section{CONCLUSIONS}

In summary, the data shown here demonstrate that acute haloperidol administration increased NT mRNA levels in the striatum of $\mathrm{D}_{3}$ receptor deficient mice, indicating that expression of this neuropeptide can be regulated by $\mathrm{D}_{3}$ receptor-independent processes. Similarly, deletion of the $\mathrm{D}_{3}$ dopamine receptor did not alter the ability of cocaine and amphetamine to stimulate neurons in the nucleus accumbens to express NT. However, the absence of $D_{3}$ receptors altered dorsal striatal NT responses to repeated cocaine, suggesting the participation of $\mathrm{D}_{3}$ receptors in dopamine-regulated NT gene expression after long-term administration of psychostimulant drugs. $\mathrm{D}_{3}$ receptor deficient mice showed typical locomotor responses after acute administration of psychostimulants as well as normal behavioral sensitization to cocaine.

These findings demonstrate that $\mathrm{D}_{1}$ and $\mathrm{D}_{2}$ dopamine receptors can function without $\mathrm{D}_{3}$ receptors in the control of NT gene expression and motor behavior by psychomotor stimulants and antipsychotic drugs.

\section{ACKNOWLEDGMENTS}

We thank Dr. E. Ronald de Kloet (Leiden University, The Netherlands) for providing the facilities for the behavioral analysis using Ethovision. C.B. was supported by the INSERM (Institut National de la Santé et de la Recherche Médicale), and I.L.-L. by a fellowship from the Ministère de l'Education Nationale, de l’Enseignement Supérieur et de la Recherche, France.

\section{REFERENCES}

Accili D, Fishburn CS, Drago J, Steiner H, Lachowicz JE, Park BH, Gauda EB, Lee EJ, Cool MH, Sibley DR, Gerfen CR, Westphal H, Fuchs S (1996): A targeted mutation of the $\mathrm{D}_{3}$ dopamine receptor gene is associated with hyperactivity in mice. Proc Natl Acad Sci U S A 93:1945-1949

Alexander MJ, Miller MA, Dorsa DM, Bullock BP, Melloni RH Jr, Dobner PR, Leeman SE (1989): Distribution of neurotensin/neuromedin $\mathrm{N}$ mRNA in rat forebrain: Unexpected abundance in hippocampus and subiculum. Proc Natl Acad Sci U S A 86:5202-5206

Augood SJ, Kiyama H, Faull RLM, Emson PC (1991): Differential effects of acute dopaminergic $D_{1}$ and $D_{2}$ receptor antagonists on proneurotensin mRNA expression in rat striatum. Mol Brain Res 9:341-346

Augood SJ, Westmore K, Emson PC (1997): Phenotypic characterization of neurotensin messenger RNA-expressing cells in the neuroleptic-treated rat striatum: A detailed cellular co-expression study. Neuroscience 76:763-774

Betancur C, Rostène W, Bérod A (1997): Chronic cocaine increases neurotensin gene expression in the shell of the nucleus accumbens and in discrete regions of the striatum. Mol Brain Res 44:334-340

Betancur C, Cabrera R, de Kloet ER, Pélaprat D, Rostène W (1998): Role of endogenous neurotensin in the behavioral and neuroendocrine effects of cocaine. Neuropsychopharmacology 19:322-332

Bordet R, Ridray S, Carboni S, Diaz J, Sokoloff P, Schwartz JC (1997): Induction of dopamine $\mathrm{D}_{3}$ receptor expression as a mechanism of behavioral sensitization to levodopa. Proc Natl Acad Sci U S A 94:3363-3367

Boulay D, Depoortere R, Rostène W, Perrault G, Sanger DJ (1999): Dopamine $D_{3}$ receptor agonists produce similar decreases in body temperature and locomotor activity in $\mathrm{D}_{3}$ knock-out and wild-type mice. Neuropharmacology 38:555-565

Caine SB, Koob GF (1993): Modulation of cocaine selfadministration in the rat through D-3 dopamine receptors. Science 260:1814-1816 
Castel MN, Morino P, Hökfelt T (1993): Modulation of the neurotensin striato-nigral pathway by D1 receptors. Neuroreport 5:281-284

Castel MN, Morino P, Dagerlind Å, Hökfelt T (1994): Upregulation of neurotensin $\mathrm{mRNA}$ in the rat striatum after acute methamphetamine treatment. Eur J Neurosci 6:646-656

Diaz J, Lévesque D, Griffon N, Lammers CH, Martres MP, Sokoloff P, Schwartz JC (1994): Opposing roles for dopamine D2 and D3 receptors on neurotensin mRNA expression in nucleus accumbens. Eur J Neurosci 6:1384-1387

Diaz J, Lévesque D, Lammers CH, Griffon N, Martres MP, Schwartz JC, Sokoloff P (1995): Phenotypical characterization of neurons expressing the dopamine $\mathrm{D}_{3}$ receptor in the rat brain. Neuroscience 65:731-745

Ervin GN, Birkemo LS, Nemeroff CB, Prange AJ Jr (1981): Neurotensin blocks certain amphetamine-induced behaviours. Nature 291:73-76

Feldpausch DL, Needham LM, Stone MP, Althaus JS, Yamamoto BK, Svensson KA, Merchant KM (1998): The role of dopamine D4 receptor in the induction of behavioral sensitization to amphetamine and accompanying biochemical and molecular adaptations. J Pharmacol Exp Ther 286:497-508

Franklin KBJ, Paxinos G (1997): The Mouse Brain in Stereotaxic Coordinates. San Diego, Academic Press

Garver DL, Bissette G, Yao JK, Nemeroff CB (1991): Relation of CSF neurotensin concentrations to symptoms and drug response of psychotic patients. Am J Psychiatry 148:484-488

Glimcher PW, Giovino AA, Hoebel BG (1987): Neurotensin self-injection in the ventral tegmental area. Brain Res 403:147-150

Glimcher PW, Margolin DH, Giovino AA, Hoebel BG (1984): Neurotensin: A new 'reward peptide'. Brain Res 291:119-124

Hanson GR, Smiley P, Johnson M, Letter A, Bush L, Gibb JW (1989): Response by the neurotensin systems of the basal ganglia to cocaine treatment. Eur J Pharmacol $160: 23-30$

Henry DJ, Hu XT, White FJ (1998): Adaptations in the mesoaccumbens dopamine system resulting from repeated administration of dopamine D1 and D2 receptor-selective agonists: Relevance to cocaine sensitization. Psychopharmacology 140:233-242

Hoffman DC, Donovan H (1995): Catalepsy as a rodent model for detecting antipsychotic drugs with extrapyramidal side effect liability. Psychopharmacology 120:128-133

Horger BA, Taylor JR, Elsworth JD, Roth RH (1994): Preexposure to, but not cotreatment with, the neurotensin antagonist SR 48692 delays the development of cocaine sensitization. Neuropsychopharmacology 11:215-222

Jung MY, Skryabin BV, Arai M, Abbondanzo S, Fu D, Brosius J, Robakis NK, Polites HG, Pintar JE, Schmauss C (1999): Potentiation of the $D_{2}$ mutant motor phenotype in mice lacking dopamine $\mathrm{D}_{2}$ and $\mathrm{D}_{3}$ receptors. Neuroscience 91:911-924

Jung MY, Schmauss C (1999): Decreased c-fos responses to dopamine $D_{1}$ receptor agonist stimulation in mice deficient for $\mathrm{D}_{3}$ receptors. J Biol Chem 274:29406-29412
Kalivas PW, Burgess SK, Nemeroff CB, Prange AJ Jr (1983): Behavioral and neurochemical effects of neurotensin microinjection into the ventral tegmental area. Neuroscience 8:495-505

Kalivas PW, Duffy P (1990): Effect of acute and daily neurotensin and enkephalin treatments on extracellular dopamine in the nucleus accumbens. J Neurosci 10:2940-2949

Kasckow J, Nemeroff CB (1991): The neurobiology of neurotensin: Focus on neurotensin-dopamine interactions. Regul Pept 36:153-164

Kinkead B, Binder EB, Nemeroff CB (1999): Does neurotensin mediate the effects of antipsychotic drugs? Biol Psychiatry 46:340-351

Kislauskis E, Bullock B, McNeil S, Dobner PR (1988): The rat gene encoding neurotensin and neuromedin N. J Biol Chem 263:4963-4968

Koeltzow TE, Xu M, Cooper DC, Hu XT, Tonegawa S, Wolf ME, White FJ (1998): Alterations in dopamine release but not dopamine autoreceptor function in dopamine $\mathrm{D}_{3}$ receptor mutant mice. J Neurosci 18:2231-2238

Koob GF (1992): Drugs of abuse: Anatomy, pharmacology and function of reward pathways. Trends Pharmacol Sci 13:177-184

Levant B (1998): Differential distribution of $D_{3}$ dopamine receptors in the brains of several mammalian species. Brain Res 800:269-274

Levant B, Grigoriadis DE, DeSouza EB (1993): $\left[{ }^{3} \mathrm{H}\right]$ quinpirole binding to putative $D_{2}$ and $D_{3}$ dopamine receptors in rat brain and pituitary gland: A quantitative autoradiographic study. J Pharmacol Exp Ther 264:9911001

Lévesque D, Martres MP, Diaz J, Griffon N, Lammers CH, Sokoloff P, Schwartz JC (1995): A paradoxical regulation of the dopamine $\mathrm{D}_{3}$ receptor expression suggests the involvement of an anterograde factor from dopamine neurons. Proc Natl Acad Sci U S A 92:1719-1723

MacLennan AJ, Maier SF (1983): Coping and the stressinduced potentiation of stimulant stereotypy in the rat. Science 219:1091-1093

Merchant KM, Letter AA, Gibb JW, Hanson GR (1988): Changes in the limbic neurotensin systems induced by dopaminergic drugs. Eur J Pharmacol 153:1-9

Merchant KM, Bush LG, Gibb JW, Hanson GR (1989): Dopamine $\mathrm{D}_{2}$ receptors exert tonic regulation over discrete neurotensin systems of the rat brain. Brain Res 500:21-29

Merchant KM, Dobner PR, Dorsa DM (1992): Differential effects of haloperidol and clozapine on neurotensin gene transcription in rat neostriatum. J Neurosci 12:652-663

Merchant KM, Dorsa DM (1993): Differential induction of neurotensin and c-fos gene expression by typical versus atypical antipsychotics. Proc Natl Acad Sci U S A 90:3447-3451

Merchant KM, Hanson GR, Dorsa DM (1994a): Induction of neurotensin and c-fos mRNA in distinct subregions of rat neostriatum after acute methamphetamine: Comparison with acute haloperidol effects. J Pharmacol Exp Ther 269:806-812

Merchant KM, Dobie DJ, Filloux FM, Totzke M, Aravagiri 
M, Dorsa DM (1994b): Effects of chronic haloperidol and clozapine treatment on neurotensin and c-fos mRNA in rat neostriatal subregions. J Pharmacol Exp Ther 271:460-471

Merchant KM, Figur LM, Evans DL (1996): Induction of c-fos mRNA in rat medial prefrontal cortex by antipsychotic drugs: role of dopamine D2 and D3 receptors. Cereb Cortex 6:561-570

Nemeroff CB (1980): Neurotensin: Perchance an endogenous neuroleptic? Biol Psychiatry 15:283-302

Pierce RC, Kalivas PW (1997): A circuitry model of the expression of behavioral sensitization to amphetaminelike psychostimulants. Brain Res Rev 25:192-216

Pilla M, Perachon S, Sautel F, Garrido F, Mann A, Wermuth CG, Schwartz JC, Everit BJ, Sokoloff P (1999): Selective inhibition of cocaine-seeking behaviour by a partial dopamine $\mathrm{D}_{3}$ agonist. Nature 400:371-375

Ridray S, Griffon N, Mignon V, Souil E, Carboni S, Diaz J, Schwartz JC, Sokoloff P (1998): Coexpression of dopamine $D_{1}$ and $D_{3}$ receptors in islands of Calleja and shell of nucleus accumbens of the rat: Opposite and synergistic functional interactions. Eur J Neurosci 10:1676-1686

Robledo P, Maldonado R, Koob GF (1993): Neurotensin injected into the nucleus accumbens blocks the psychostimulant effects of cocaine but does not attenuate cocaine self-administration in the rat. Brain Res 622:105-112

Shafer RA, Levant B (1998): The D3 dopamine receptor in cellular and organismal function. Psychopharmacology 135:1-16

Segal DM, Moraes CT, Mash DC (1997): Up-regulation of D3 dopamine receptor mRNA in the nucleus accumbens of human cocaine fatalities. Mol Brain Res 45:335-339

Self DW, Nestler EJ (1995): Molecular mechanisms of drug reinforcement and addiction. Annu Rev Neurosci 18:463-495

Sharma RP, Janicak PG, Bissette G, Nemeroff CB (1997): CSF neurotensin concentrations and antipsychotic treatment in schizophrenia and schizoaffective disorder. Am J Psychiatry 154:1019-1021
Sirinathsinghii DJS, Schuligoi R, Heavens RP, Dixon A, Iversen SD, Hill RG (1994): Temporal changes in the messenger RNA levels of cellular immediate early genes and neurotransmitter/receptor genes in the rat neostriatum and substantia nigra after acute treatment with eticlopride, a dopamine $D_{2}$ receptor antagonist. Neuroscience 62:407-423

Snijders R, Kramarcy NR, Hurd RW, Nemeroff CB, Dunn AJ (1982): Neurotensin induces catalepsy in mice. Neuropharmacology 21:465-468

Sokoloff P, Giros B, Martres MP, Bouthenet ML, Schwartz JC (1990): Molecular cloning and characterization of a novel dopamine receptor $\left(D_{3}\right)$ as a target for neuroleptics. Nature 347:146-151

Staley JK, Mash DC (1996): Adaptive increase in D3 dopamine receptors in the brain reward circuits of human cocaine fatalities. J Neurosci 16:6100-6106

Tremblay M, Rouillard C, Lévesque D (1997): Dopamine $D_{1}$ receptor antisense reduces neuropeptide mRNA levels in rat nucleus accumbens. Neuroreport 8:3901-3905

Wallace DR, Mactutus CF, Booze RM (1996): Repeated intravenous cocaine administration: Locomotor activity and dopamine D2/D3 receptors. Synapse 23:152-163

Widerlöv E, Lindström LH, Besev G, Manberg PJ, Nemeroff CB, Breese GR, Kizer JS, Prange AJ Jr (1982): Subnormal CSF levels of neurotensin in a subgroup of schizophrenic patients: Normalization after neuroleptic treatment. Am J Psychiatry 139:1122-1126

Wise RA (1995): $D_{1}$ - and $D_{2}$-type contributions to psychomotor sensitization and reward: Implications for pharmacological treatment strategies. Clin Neuropharmacol 18:S74-S83

Xu M, Koeltzow TE, Tirado-Santiago G, Moratalla R, Cooper DC, Hu XT, White NM, Graybiel, AM, White FJ, Tonegawa S (1997): Dopamine D3 receptor mutant mice exhibit increased behavioral sensitivity to concurrent stimulation of D1 and D2 receptors. Neuron 19:837-848

Yung KK, Bolam JP, Smith AD, Hersch SM, Ciliax BJ, Levey AI (1995): Immunocytochemical localization of D1 and D2 dopamine receptors in the basal ganglia of the rat: Light and electron microscopy. Neuroscience 65:709-730 